NBER WORKING PAPER SERIES

ESTIMATED IMPACT OF THE FED'S MORTGAGE-BACKED SECURITIES PURCHASE PROGRAM

Johannes C. Stroebel

John B. Taylor

Working Paper 15626

http://www.nber.org/papers/w15626

\author{
NATIONAL BUREAU OF ECONOMIC RESEARCH \\ 1050 Massachusetts Avenue \\ Cambridge, MA 02138
}

December 2009

We would like to thank Jim Dignan, Peter Frederico, Frank Nothaft and Josie Smith for helpful comments. The views expressed herein are those of the author(s) and do not necessarily reflect the views of the National Bureau of Economic Research.

NBER working papers are circulated for discussion and comment purposes. They have not been peerreviewed or been subject to the review by the NBER Board of Directors that accompanies official NBER publications.

(C) 2009 by Johannes C. Stroebel and John B. Taylor. All rights reserved. Short sections of text, not to exceed two paragraphs, may be quoted without explicit permission provided that full credit, including (C) notice, is given to the source. 
Estimated Impact of the Fed's Mortgage-Backed Securities Purchase Program

Johannes C. Stroebel and John B. Taylor

NBER Working Paper No. 15626

December 2009

JEL No. E52,G12

\begin{abstract}
$\underline{\text { ABSTRACT }}$
We examine the quantitative impact of the Federal Reserve's mortgage-backed securities (MBS) purchase program. We focus on how much of the recent decline in mortgage interest rate spreads can be attributed to these purchases. The question is more difficult than frequently perceived because of simultaneous changes in prepayment and default risks. When we control for these risks, we find evidence of statistically insignificant or small effects of the program. For specifications where the existence or announcement of the program appears to have lowered spreads, we find no separate effect of the size of the stock of MBS purchased by the Fed.
\end{abstract}

Johannes C. Stroebel

Department of Economics

Stanford University

Stanford, California 94305

jcstroebel@googlemail.com

John B. Taylor

Herbert Hoover Memorial Building

Stanford University

Stanford, CA 94305-6010

and NBER

John.Taylor@stanford.edu 


\title{
Estimated Impact of the Fed's Mortgage-Backed Securities Purchase Program
}

\author{
Johannes C. Stroebel and John B. Taylor* \\ Stanford University
}

December 2009

\begin{abstract}
We examine the quantitative impact of the Federal Reserve's mortgagebacked securities (MBS) purchase program. We focus on how much of the recent decline in mortgage interest rate spreads can be attributed to these purchases. The question is more difficult than frequently perceived because of simultaneous changes in prepayment and default risks. When we control for these risks, we find evidence of statistically insignificant or small effects of the program. For specifications where the existence or announcement of the program appears to have lowered spreads, we find no separate effect of the size of the stock of MBS purchased by the Fed.
\end{abstract}

Following the steep decline in house prices throughout 2007 and 2008, and the associated crisis in the financial system, the Federal Reserve introduced several programs with the aim of stabilizing the housing market. Most significantly it established a program to purchase mortgagebacked securities (MBS) that were guaranteed by Fannie Mae and Freddie Mac, the two government sponsored enterprises (GSE) with this role. The program was set up with an initial limit of $\$ 500 \mathrm{bn}$, but was later expanded to $\$ 1.25$ trillion. The Fed also created a program to buy GSE-debt—initially up to \$100bn and later expanded to \$200bn—and a program to purchase \$300bn of medium-term Treasury securities. The Fed’s MBS purchases came on top of an earlier announced Treasury MBS purchase program.

These programs were introduced with the explicit aim of reducing mortgage interest rates. ${ }^{1}$ Figure 1 shows both primary and secondary mortgage interest rates spreads over Treasury

\footnotetext{
* We would like to thank Jim Dignan, Peter Frederico, Frank Nothaft and Josie Smith for helpful comments.

${ }^{1}$ The Press Release on November 25, 2008 announcing the MBS-purchase and GSE-debt purchase programs stated that "This action is being taken to reduce the cost and increase the availability of credit for the purchase of houses, which in turn should support housing markets and foster improved conditions in financial markets more generally."
} 
yields during the financial crisis. Primary mortgage rates are the rates that are paid by the individual borrower. They are based on the secondary market rate but also include a fee for the GSE insurance, a servicing spread to cover the cost of the mortgage servicer, and an originator spread.

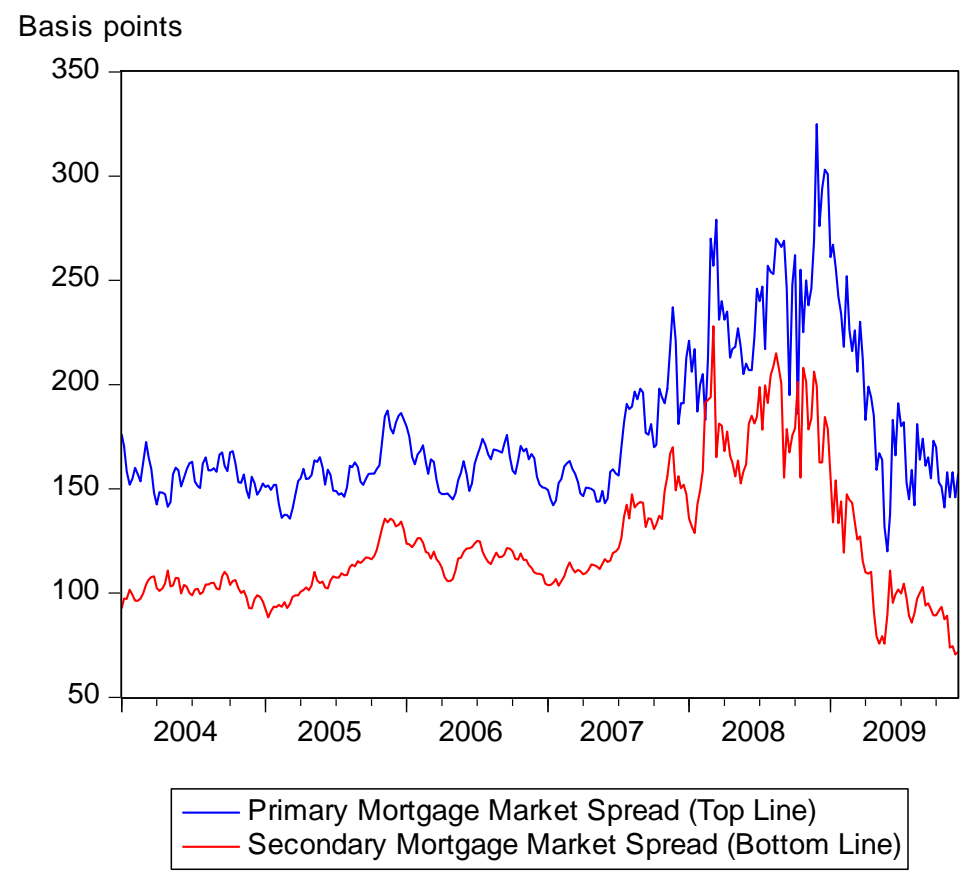

\section{Figure 1: Development of Mortgage Interest Spreads ${ }^{2}$}

Observe that mortgage spreads over U.S. Treasuries started rising in 2007 and continued rising until late 2008 when they reached a peak and started declining. By July 2009 they had returned to their long-run average—or slightly below that average—and then did not move significantly further. Two related questions about these movements in mortgage spreads are

\footnotetext{
${ }^{2}$ The primary market mortgage rate series comes from Freddie Mac's Primary Mortgage Market Survey, which surveys lenders each week on the rates and points for their most popular 30-year fixed-rate, 15-year fixed-rate, 5/1 hybrid amortizing adjustable-rate, and 1-year amortizing adjustable-rate mortgage products. The secondary market mortgage is the Fannie Mae MBS 30 Year Current Coupon. The spreads are created by subtracting the yield on 10year treasuries from both series. The maturity difference between these series captures the fact that most 30-year mortgages are paid-off or refinanced before their maturity.
} 
important to address. First, to what degree can the decline in spreads to their long-run levels in 2009 be attributed to the purchases of MBS by Fed and Treasury? Second, could additional MBS purchases reduce mortgage spreads further? These questions are of interest for determining whether or not to extend the program. But they also matter in the long run. Determining whether central banks have the ability to affect pricing of mortgage securities for extended periods is important input into the debate about the role, responsibilities and powers of central banks (see, for example, the collection of essays on this subject in Ciorciari and Taylor, 2009).

\section{Conventional Wisdom About the Impact of the MBS Purchase Program}

A common perception is that the MBS purchase program has been successful in reducing borrowing costs for home buyers. In January 2009, Ben Bernanke announced in a speech at the London School of Economics that "[...] mortgage rates dropped significantly on the announcement of this program and have fallen further since it went into operation." A quick glance at Figure 2 could support such a claim. The decline in mortgage interest rate spread is contemporaneous to the expansion of the MBS purchase program More recently, on December 2, 2009, Executive Vice President of the Markets Group at the Federal Reserve Bank of New York Brian Sack stated that: "The effects on the MBS rate... can be seen most easily in the spread of yields on mortgage-backed securities over those on Treasuries, adjusted for the prepayment option embedded in those securities. The option-adjusted spread has narrowed by about 100 basis points since the announcement of the program, with more than half of that decline occurring on days of substantive statements about the MBS purchase program.” 


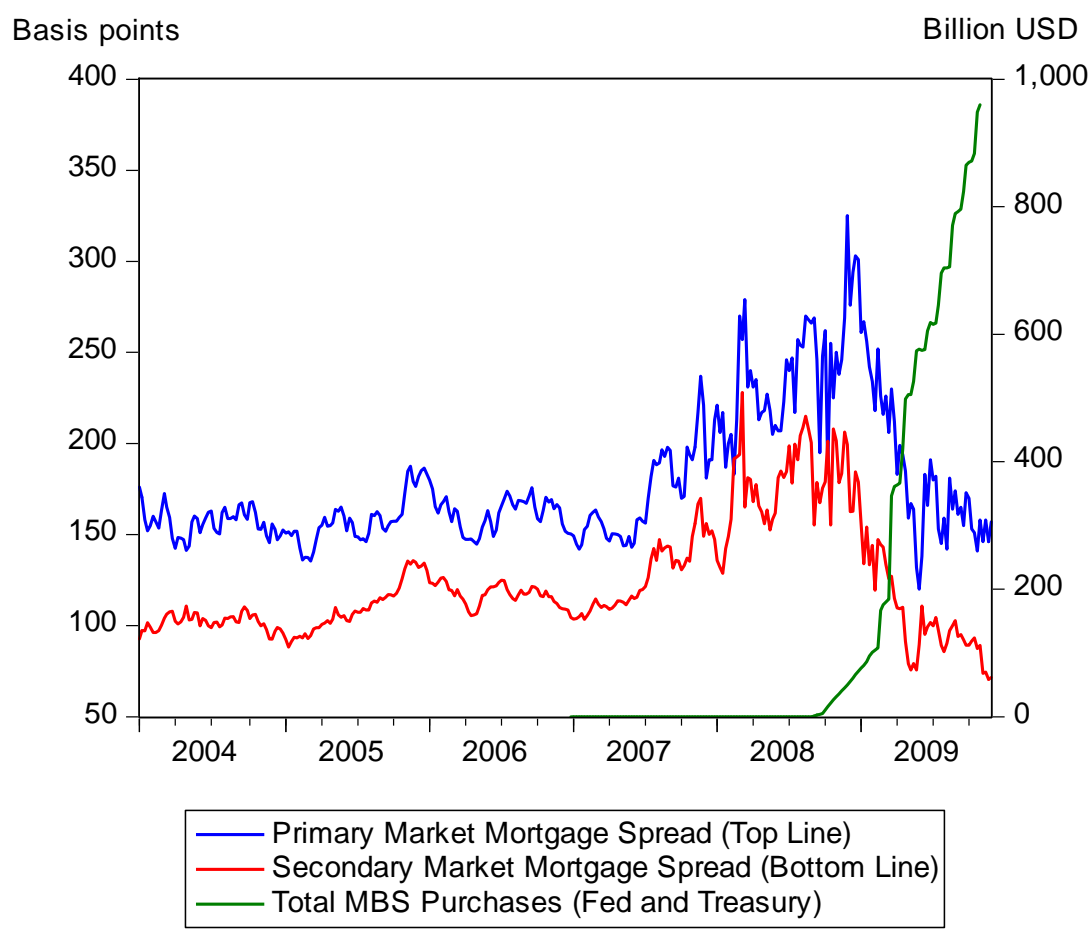

Figure 2: Mortgage Spreads and Stock of MBS purchases

Others cite the large fraction of new agency-insured MBS issuance that the Fed has purchased each month since the start of the purchase program ${ }^{3}$. Figure 3 shows that MBS purchases in 2009 were between 20 percent and 130 percent of new issuance, and a significantly larger fraction of net issuance.

\footnotetext{
${ }^{3}$ This point was made by Brian Sack who asked: "How has the Fed been able to generate these substantial effects on longer-term interest rates? One word: size. The total amount of securities to be purchased under the LSAPs is quite large relative to the size of the relevant markets. That is particularly the case for mortgage-backed securities. Fed purchases to date have run at more than two times the net issuance of securities in this market.” (Sack, 2009)
} 


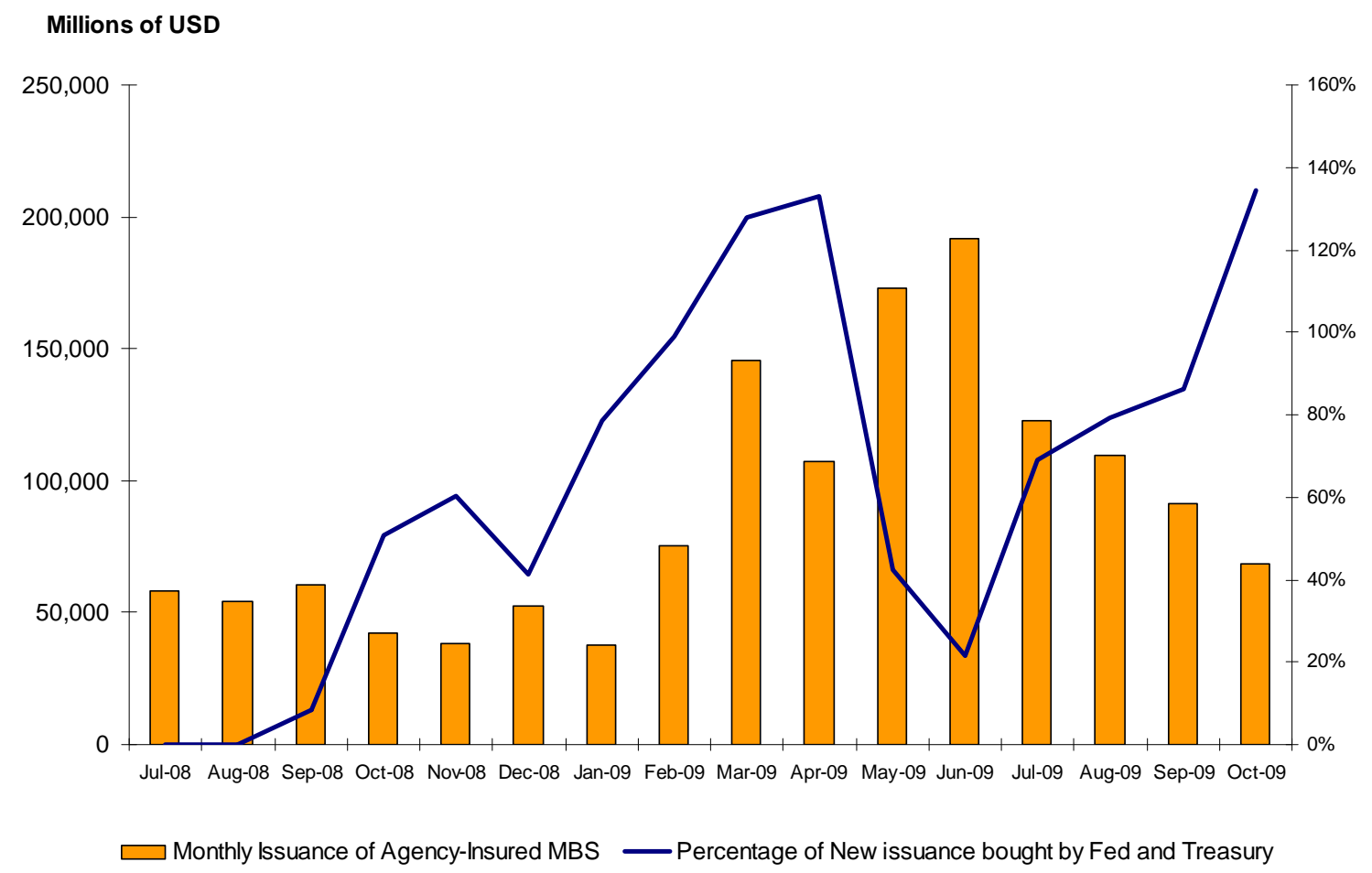

Figure 3: Monthly Flows of MBS Issues and Shares Bought by Fed and Treasury

However, in our view it is important to determine whether such statements can be supported by econometric analysis that controls for influences other than the MBS purchase program on mortgage rates. In particular, any coherent story that links the decline in mortgage interest rates to the purchases of MBS by the Fed needs to also explain why mortgage spreads increased so dramatically between 2007 and late 2008, and consider whether those same factors may be responsible for at least part of the subsequent decline in 2009. It is conceivable that precisely those indicators of risk in mortgage lending that drove up mortgage spreads through 2007 and 2008 relaxed throughout the first half of 2009, providing a coherent theory for both the rise and the subsequent fall of mortgage spreads, without a large role for the government purchases. 
In our view, the minutes of the Federal Open Market Committee meeting on June 23-24 2009 set the correct benchmark for analysis: "The asset purchase programs were intended to support economic activity by improving market functioning and reducing interest rates on mortgage loans and other long-term credit to households and businesses relative to what they otherwise would have been (emphasis added).” Such a comparison requires a statistical procedure to determine how interest rates on mortgage are affected by other factors, including risks. To control for these risks we use multivariate regression techniques. We focus on prepayment risks and default risks as explained below.

\section{Controlling for Prepayment Risk}

Mortgage-backed securities are structured products that are collateralized by residential mortgages. Most of these mortgages entail a prepayment option by the individual borrower, which gives the borrower the right to prepay the mortgage at any time prior to the maturity of the loan, and thereby to refinance at a favorable rate. This prepayment option gives mortgage-backed securities characteristics similar to those of a callable bond in which the issuer has the right to redeem prior to its maturity date (Windas, 1996). Pricing of a mortgage-backed security thus proceeds by modeling it as a combination of (1) a long position in a non-callable bond and (2) a short position in a prepayment option. The combined valuation of those two parts determines the secondary market yield of MBS.

The value of the prepayment option is determined using standard option-pricing tools, where the value of the option depends on expected movements in the short-term interest rate higher volatility in the interest rate will increase the value of the option, since it will increase the probability of states in which prepayment becomes optimal. The option-adjusted spread (OAS) is 
a common way for investors and traders to take account of the prepayment risk. The OAS is the spread of the MBS over a term structure of alternative interest rates after controlling for the value of the prepayment option. A summary of the OAS calculation is provided in the appendix.

Given these considerations we focus on the impact of the MBS purchase program on the OAS. An advantage of the OAS is that the measure directly controls for prepayment risk without adding control variables in the statistical analysis. We also examine the impact on the primary and secondary market spreads shown in Figures 1 and 2, but in this case it is necessary control for prepayment risk indirectly by including other terms in the regressions, such as the implied volatility of Treasury yields obtained from options on those securities, ${ }^{4}$ as in Lehnert, Passmore and Sherlund (2006). Higher volatility in Treasury yields would increase prepayment risk and thus the primary or secondary mortgage interest rate spread.

\section{Controlling for Default Risk}

Controlling for default risk of GSE-insured MBS is necessary to ensure that the decline in mortgage spreads in 2009 was not driven by a decline in default risk. Finding a good measure for default risk, however, is not easy.

In the case of GSE-insured MBS, the default risk is related to the default risk of the underlying mortgages as well as to the potential of the insuring GSE being unable to meet its guarantee obligations. The ability to fulfill its pledge is a function of the health of the housing market and of a number of political factors that determine whether the government would eventually act as a backstop to GSE-issued guarantees. A good measure of the default risk of GSE-insured MBS is the credit default swap (CDS) series on GSE-debt. When there is an

\footnotetext{
${ }^{4}$ Bloomberg Ticker: MOVE.IND - This is a yield curve weighted index of the normalized implied volatility on 1month Treasury options.
} 
increased risk of default of agency-debt, as measured by higher costs for CDS on that debt, the risk that the GSEs will not be able to fulfill their insurance pledge increases, and secondary market spreads on agency-insured MBS will increase. Unfortunately, placing Fannie Mae and Freddie Mac into conservatorship on September 7, 2008 was a trigger-event for outstanding CDS so the data series stops at that time, and, to our knowledge, no new CDS series have emerged since then that would allow us to directly measure GSE default risk.

An alternative proxy for the default risk of Fannie and Freddie is the spread between agency-debt and US Treasury securities. One such series ${ }^{5}$ is the spread between 5-year Fannie Mae bonds and US Treasury active (on-the-run) ${ }^{6}$ securities. Figure 4 shows this bond spread series since 2007 together with the associated CDS series prior to its discontinuation ${ }^{7}$. For the time-period that the two series co-exist, they are highly correlated, which suggests that the bond spread series is a good control for the default risk of GSE-insured MBS.

\footnotetext{
${ }^{5}$ Bloomberg Ticker FNMGVN5:IND 5 Year; Robustness checks using the 10-year GSE debt series, FNMGVN10:IND, provide very similar results.

${ }^{6}$ If US Treasury actives are not available for the underlying benchmark Fannie Mae term, then the closest to the maturity for Fannie Mae is used.

${ }^{7}$ Bloomberg Ticker: FNMA 5YR CDS SR Index
} 


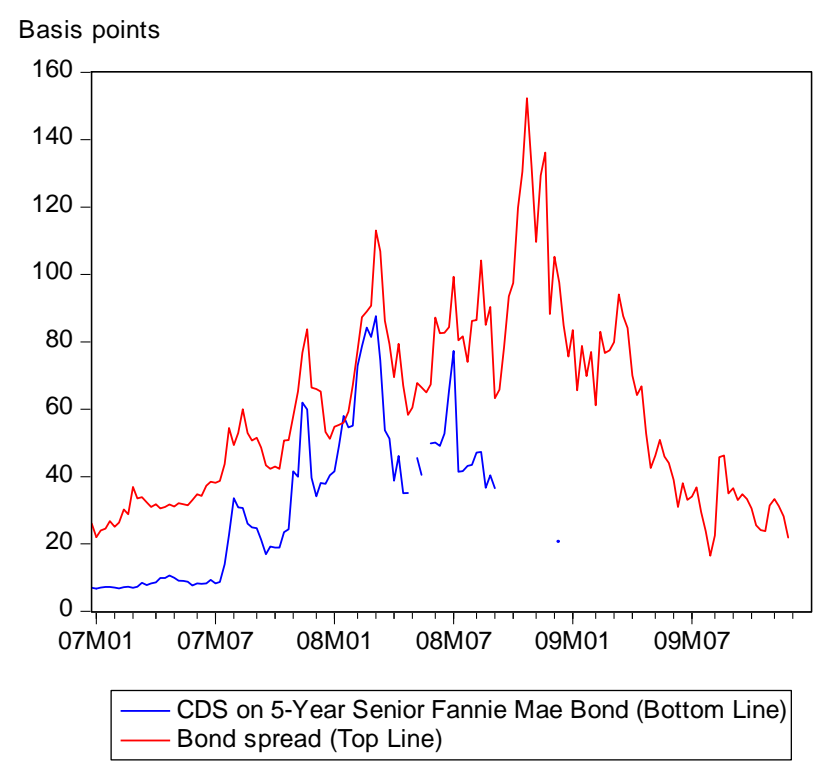

Figure 4: GSE bond spreads vs. GSE CDS

A complicating factor however is that in late 2008 the Fed also embarked on a program to purchase agency debt. While these interventions capture a much smaller fraction of the market than the purchases of agency-insured MBS, they may contaminate the usefulness of bond spreads as a pure measure of agency default risk during this period. To deal with this problem we take two approaches.

First, we instrument for the bond spread series with three instrumental variables: the level of the Case-Shiller house price index, the month-on-month change in this index, and Moody's AAA bond index ${ }^{8}$. (We interpolate the monthly Case-Shiller index data to get the weekly observations.) A lower level of the house price index and a large month-on-month decline in the index should indicate a higher degree of mortgage risk. Falling house prices will push borrowers

\footnotetext{
${ }^{8}$ Moody's Long-Term Corporate Bond Yield Averages are derived from pricing data on a regularly replenished population of corporate bonds in the U.S. market, each with current outstandings over \$100 million. The bonds have maturities as close as possible to 30 years; they are dropped from the list if their remaining life falls below 20 years, if they are susceptible to redemption, or if their ratings change. All yields are yield-to- maturity calculated on a semi-annual basis. Each observation is an unweighted average
} 
into negative home equity, increasing their incentives for strategic default, and thus increasing the risk of mortgage default. The Moody's AAA bond index captures the general degree of riskiness in the credit markets. Because these instruments are unlikely to be affected by government purchases of GSE-debt and are highly correlated with the bond spread (the first stage regression has an F-Statistic of 141.16), they are good instruments in our view. In addition, beyond its effect through capturing increased risk in the housing credit market, neither of the instruments should have a dramatic effect on the default probability of GSE-debt - thus the exclusion restrictions are likely to be met.

Second, we use the spreads of Fannie Mae’s Subordinated Benchmark note series to proxy for credit risk. Since the Fed's GSE-debt purchases are focused on the senior debt market, these are less likely to have contaminated this subordinated debt as a proxy of risk. Fannie Mae started issuing subordinated debt in 2001, with the expressed goal of "enhancing market discipline, transparency and capital adequacy.” The subordinated debt series is unsecured and ranks junior in priority of payment to all senior creditors, so "investors considering investing in these securities need to closely monitor Fannie Mae’s financial strength, safety and soundness” (Fannie Mae, 2001). Since MBS guarantees rank pari passu to senior bonds, the subordinated debt will only be repaid if the MBS insurances issued are fulfilled. This means that an increase in the subordinated debt spreads could signal an increase in the probability of default for the GSEinsured MBS, and thus the secondary market mortgage interest rates. The downside of looking at the subordinated debt series is its very small volume, which is usually around $\$ 1$ bn per issuance, and not comparable in liquidity to the senior GSE bonds. Therefore, the pricing of these securities may conflate liquidity elements with credit risk elements. Figure 5 compares the development of the bond spread series with the subordinated debt spread series - it appears as if 
the subordinated debt spread series moves more dramatically, especially in the period running up to the conservatorship of Fannie and Freddie, and may thus be more able to pick up changes in default risk.

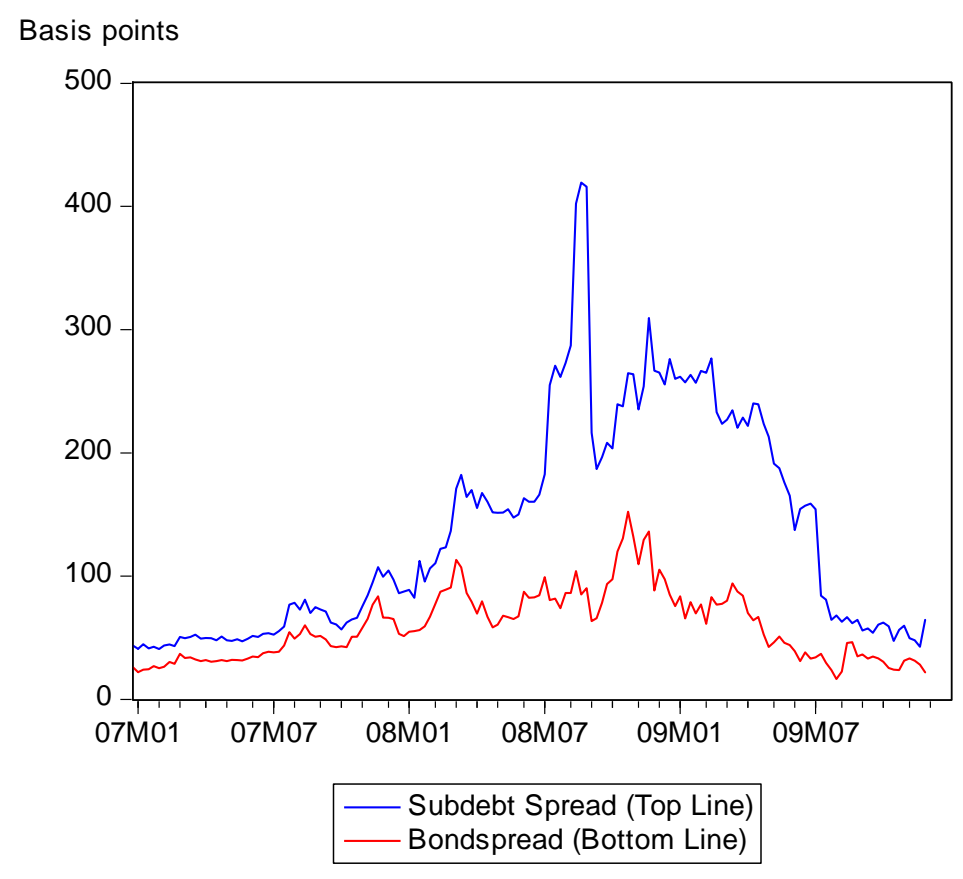

Figure 5: GSE 5-year bond spread vs. GSE Subordinated debt Spread $^{9}$

\section{Regression Results with the Option-Adjusted Spread}

We first regress the option-adjusted spread on the various measures of default risk (interest rate spreads on GSE senior debt — with and without instruments — as well as on subordinated debt) and the stock of GSE-secured MBS held by Fed and Treasury as a percentage of the total market (about $\$ 5$ trillion). Both the outcome variables and the bond spreads are measured in basis points (1/100 of a percentage point). The observations are at a weekly

\footnotetext{
${ }^{9}$ Spread of the Fannie Mae Subordinated Benchmark Series, Maturity on 5.1.2013, Volume: \$1bn (Bloomberg Ticker: FNMA 4.625 05/01/13 Corp) over 5-year Treasury.
} 
frequency; for higher frequency series, we take the observation closest to the beginning of the week. The estimation period is the beginning of 2007 to the December 2009.

As discussed above, the option-adjusted spread is measured against a term structure of interest rates. The predicted prepayment cash-flows associated with the MBS are discounted back to the present using this term structure, and the OAS is the number of basis points that the discount curve needs to be adjusted upwards until the theoretical price calculated using the "adjusted term structure" matches the market price of the security. It is common to use the LIBOR swap curve for this purpose. LIBOR swap rates are the most appropriate discount rate for most financial market actors, since portfolio managers need to balance mortgage investments with other non-government investments. The Swap curve provides a measure of the opportunity cost of most investors. For example, Fabozzi and Mann (2001) argue that "funded investors use LIBOR as their benchmark interest rate. Most funded investors borrow at a spread over LIBOR. Consequently, if a yield curve for LIBOR is used as the benchmark interest rate, the OAS reflects a spread relative to their funding costs." Figure 6 shows the OAS using the swap curve, which we call Swap-OAS, along with the primary mortgage market spread. Note that the SwapOAS has the same general pattern as the primary mortgage spread, but the gap between them narrows and then widens again over the sample period. 


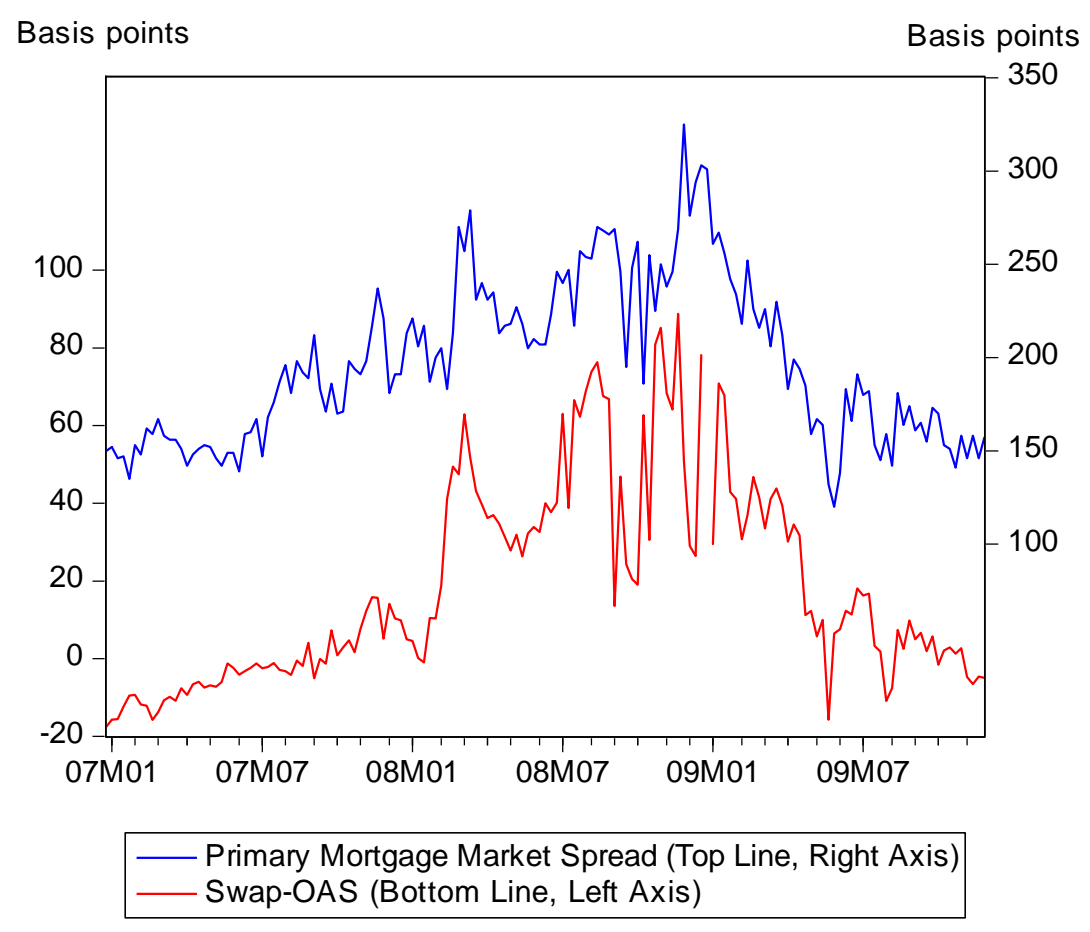

Figure 6: Swap-OAS

The OAS can also be calculated using the Treasury spot curve rather than the LIBOR swap curve for the term structure. Treasury rates and LIBOR have different liquidity and risk characteristics and these varied considerably during the financial crisis as Treasury rates deviated significantly from LIBOR due in part to a "flight to quality.” (Smith, 2009; Taylor and Williams, 2008). We consider this alternative measure, which we call Treasury-OAS, ${ }^{10}$ as well as the Swap-OAS and in our analysis.

\footnotetext{
${ }^{10}$ For Swap-OAS we use the NOASFNCL series of Bloomberg. For Treasury OAS was use the MOASFNCL series. Both series find the OAS of FNMA 30 Year Current Coupon MBS. NOASFNCL uses the S23 Swap curve, MOASFNCL uses the Constant Maturity Treasury (CMT) curve for discounting.
} 
In Tables 1 and 2 we report the impact of MBS purchases on the Swap-OAS. We use the GSE bond spread series discussed in Section 3 as a measure of the underlying default risk in Table 1 and subordinated debt spreads in Table 2. Recall that we do not need to proxy for volatility, because prepayment risk is already removed from the OAS series.

Table 1: Swap-OAS regressions with GSE bond spreads

\begin{tabular}{ccccc}
\hline & $(1)$ & $(2)$ & $(3)$ & $(4)$ \\
\hline \hline & OLS & IV & OLS & IV \\
Bond spreads & 0.85 & 0.88 & 0.44 & 0.33 \\
& $(0.04)$ & $(0.05)$ & $(0.06)$ & $(0.08)$ \\
Total MBS & 68.74 & & & \\
Purchases & $(21.16)$ & $(24.66)$ & $(17.55)$ & 17.74 \\
& & & & $(21.52)$ \\
OAS (t-1) & & & 0.52 & 0.62 \\
& & & $(0.06)$ & $(0.07)$ \\
\hline Number of & 148 & 143 & 147 & 142 \\
Observations & & 0.741 & 0.836 & 0.829 \\
$\mathrm{R}^{2}$ & 0.750 & & &
\end{tabular}

Observe in Table 1 that the OAS moves closely with the bond spread, just as theory would predict. However, the coefficient on the MBS purchase volume is of the wrong sign and sometimes insignificant. There is no evidence that the increase in the MBS purchases led to a reduction in mortgage interest rate spreads using this conventional OAS measure. 
Table 2: Swap-OAS Regressions with Subordinated Debt Spreads

\begin{tabular}{ccccc}
\hline \hline & $(1)$ & $(2)$ & $(3)$ & $(4)$ \\
\hline & OLS & IV & OLS & IV \\
Subdebt Spread & 0.25 & & & 0.16 \\
& $(0.01)$ & $(0.01)$ & $(0.02)$ & $(0.03)$ \\
Total MBS & & & & \\
Purchases & $(20.12)$ & $(23.44)$ & $(17.34)$ & -41.23 \\
& & & & $(20.74)$ \\
OAS (t-1) & & & 0.52 & 0.41 \\
\hline Number of & 148 & & $(0.073)$ & $(0.102)$ \\
Observations & & 143 & 147 & 142 \\
$\mathrm{R}^{2}$ & 0.737 & 0.735 & 0.810 & 0.805
\end{tabular}

The regressions in Table 2 control for default risk using the subordinated debt series. Here the coefficients on the MBS purchases have the correct sign, but are quite small and sometimes statistically insignificant. For example, the coefficient on total MBS purchases in column (1) suggests that a purchase of $\$ 500$ billion in MBS (approximately 10\% of the market) would reduce the Swap-OAS by about 4 basis points. Accordingly, the actual total purchases of Fed and Treasury up to December 2009 would have contributed a total of 8 basis points to the decline in the Swap-OAS.

Tables 3 and 4 consider the same regressions as Tables 1 and 2 except that the alternative OAS measure, Treasury-OAS, replaces Swap-OAS as the dependent variable. The results show a larger and more significant effect of the MBS purchases on the Treasury-OAS. The differences in the parameter estimates using the Swap-OAS and the Treasury-OAS are driven by movements of the Treasury term structure relative to the swap-curve term structure over the sample period. 
Table 3: Treasury-OAS Regressions with GSE bond spreads

\begin{tabular}{ccccc}
\hline \hline & $(1)$ & $(2)$ & $(3)$ & $(4)$ \\
\hline \hline & OLS & IV & OLS & IV \\
Bond spreads & 0.88 & 0.78 & 0.47 & 0.29 \\
& $(0.06)$ & $(0.07)$ & $(0.07)$ & $(0.09)$ \\
Total MBS & -273.34 & $-326 . .52$ & -133.48 & -140.39 \\
Purchases & $(28.90)$ & $(33.40)$ & $(29.65)$ & $(35.10)$ \\
& & & & \\
OAS (t-1) & & & 0.49 & 0.61 \\
& & & $(0.06)$ & $(0.07)$ \\
\hline Number of & 149 & 144 & 149 & 144 \\
Observations & & & & \\
$\mathrm{R}^{2}$ & 0.772 & 0.759 & 0.841 & 0.823
\end{tabular}

Table 4: Treasury-OAS Regressions with Subordinated Debt Spreads

\begin{tabular}{ccccc}
\hline \hline & $(1)$ & $(2)$ & $(3)$ & $(4)$ \\
\hline \hline & OLS & IV & OLS & IV \\
Subdebt Spread & 0.21 & 0.21 & 0.06 & 0.05 \\
& $(0.02)$ & $(0.02)$ & $(0.02)$ & $(0.09)$ \\
& & & & \\
Total MBS & -396.29 & -447.14 & -134.94 & -150.43 \\
Purchases & $(33.69)$ & $(38.47)$ & $(35.06)$ & $(42.11)$ \\
& & & & \\
OAS (t-1) & & & 0.68 & 069 \\
& & & $(0.06)$ & $(0.07)$ \\
\hline Number of & 149 & 144 & 149 & 144 \\
Observations & & 0.638 & 0.801 & 0.790
\end{tabular}


To understand these differences, it is useful to consider the residuals of regressions of Swap-OAS and Treasury-OAS on the bond spread series (the risk indicator), without including the MBS purchases as an explanatory variable. Figure 7 shows the residuals from such a SwapOAS regression along with the actual and predicted Swap-OAS series over the sample period. Notice that the residuals through this whole period remain evenly spread around zero. Movements in prepayment risk (as measured by Swap-OAS) and default risk (measure by agency debt spreads) explain the major movements in mortgage spreads. Little remains to be explained by the MBS purchases. This explains why the coefficient on MBS purchases is very small in the regressions.

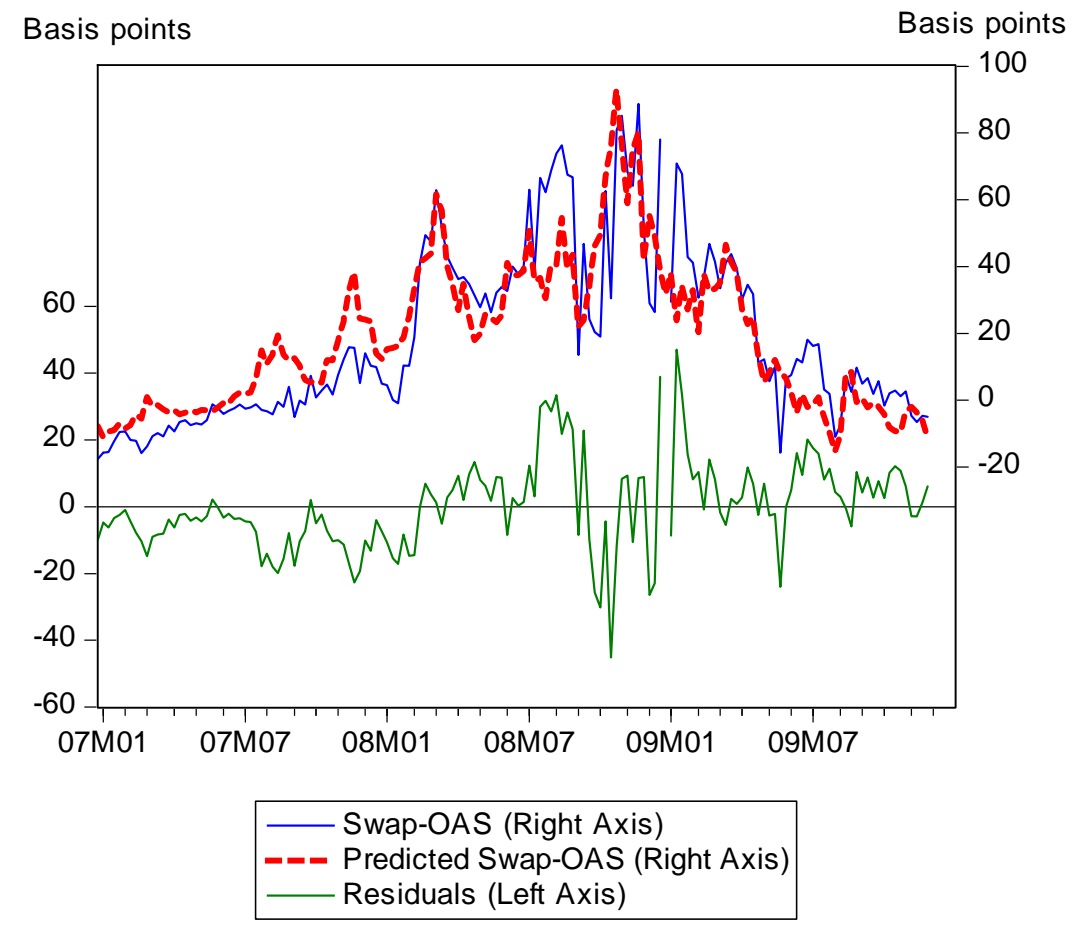

Figure 7: Residual Analysis of Swap-OAS 
Figure 8 looks at a similar analysis for the residuals from the alternative Treasury-OAS regressions. Here we see that the residuals are below zero for almost all of 2009, which is what is being picked up by the MBS purchase coefficient. More important, however, note that the residuals show little trend movement throughout 2009, as the Fed's and the Treasury's MBS stock continuously grew in size. If the volume of purchases was the driving factor, we would expect residuals to become significantly more negative over time, as purchases expanded.

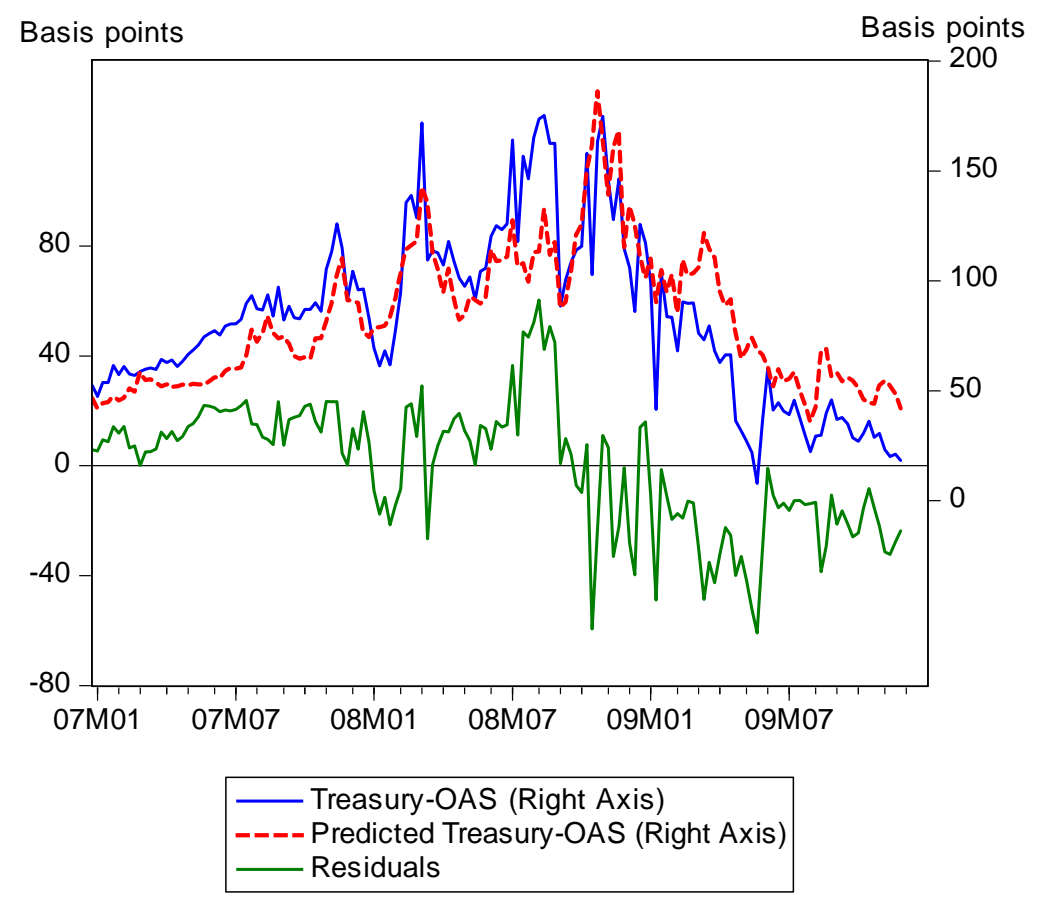

Figure 8: Residual Analysis of Treasury-OAS

Rather, it appears as if there was a single downward shift in residuals near the beginning of the MBS purchase program without a further effect from increasing purchases.

To formalize this graphical analysis mathematically, we consider OLS regressions which include a dummy variable for whether or not there was an MBS purchase program along with the variable for the volume of purchases. The results are shown in Table 5. Columns (1) through (3) 
are the swap OAS regressions corresponding to three different dummy variables: In each regression the dummy is set to 0 at the start of the sample period and then increased to 1 at a later date. In column (1) the dummy is set to 1 starting in September 2008 when the Treasury started buying MBS. In column (2) the dummy is set to 1 starting in January 2009 when the Fed purchases of MBS started. In column (3) the dummy is set to 1 starting with the announcement of the Fed's MBS purchase program on November 25, 2008. As suggested by the residual analysis in Figure 7, neither the program's existence nor the volume of purchases has a statistically significant effect on the Swap-OAS. The coefficients are insignificant or of the wrong sign.

Table 5: Option Adjusted Spread with Program Dummies

\begin{tabular}{|c|c|c|c|c|c|c|}
\hline & $\begin{array}{c}\text { (1) } \\
\text { Swap - OAS }\end{array}$ & $\begin{array}{c}(2) \\
\text { Swap - OAS }\end{array}$ & $\begin{array}{c}\text { (3) } \\
\text { Swap - OAS }\end{array}$ & $\begin{array}{c}\text { (4) } \\
\text { Treasury - } \\
\text { OAS }\end{array}$ & $\begin{array}{c}\text { (5) } \\
\text { Treasury - } \\
\text { OAS } \\
\end{array}$ & $\begin{array}{c}\text { (6) } \\
\text { Treasury - } \\
\text { OAS } \\
\end{array}$ \\
\hline Bond spreads & $\begin{array}{c}0.85 \\
(0.05)\end{array}$ & $\begin{array}{c}0.83 \\
(0.04)\end{array}$ & $\begin{array}{c}0.82 \\
(0.04)\end{array}$ & $\begin{array}{c}1.13 \\
(0.06)\end{array}$ & $\begin{array}{c}0.92 \\
(0.06)\end{array}$ & $\begin{array}{c}0.96 \\
(0.06)\end{array}$ \\
\hline $\begin{array}{l}\text { Total MBS } \\
\text { Purchases }\end{array}$ & $\begin{array}{c}70.89 \\
(35.70)\end{array}$ & $\begin{array}{c}4.99 \\
(40.84)\end{array}$ & $\begin{array}{c}-0.10 \\
(35.81)\end{array}$ & $\begin{array}{c}-43.83 \\
(41.99)\end{array}$ & $\begin{array}{l}-66.63 \\
(52.66)\end{array}$ & $\begin{array}{l}-73.97 \\
(44.44)\end{array}$ \\
\hline $\begin{array}{c}\text { MBS } \\
\text { Treasury } \\
\text { Dummy }\end{array}$ & $\begin{array}{l}-0.28 \\
(3.80)\end{array}$ & & & $\begin{array}{l}-30.46 \\
(4.45)\end{array}$ & & \\
\hline $\begin{array}{l}\text { MBS Fed } \\
\text { Dummy }\end{array}$ & & $\begin{array}{c}8.81 \\
(4.84)\end{array}$ & & & $\begin{array}{l}-28.54 \\
(6.23)\end{array}$ & \\
\hline $\begin{array}{l}\text { MBS Fed } \\
\text { Announce } \\
\text { Dummy }\end{array}$ & & & $\begin{array}{c}9.47 \\
(4.01)\end{array}$ & & & $\begin{array}{l}-27.47 \\
(4.93)\end{array}$ \\
\hline $\begin{array}{c}\text { Number of } \\
\text { Observations }\end{array}$ & 148 & 148 & 148 & 149 & 149 & 149 \\
\hline $\mathrm{R}^{2}$ & 0.746 & 0.751 & 0.760 & 0.828 & 0.80 & 0.813 \\
\hline
\end{tabular}


Columns (4) through (6) of Table 5 show the same three regressions for the alternative Treasury-OAS measure. These regressions show that the existence or the announcement of the MBS purchase program reduced the Treasury-OAS by about 30bps. However, the actual volume of the MBS held by Fed and Treasury has no additional statistically significant effect on the Treasury-OAS.

One explanation of the difference between the effect of the program's existence or announcement and the effect of the volume of purchases is that the program signaled that implicit Federal government guarantees of the GSEs had become explicit. If investors believed that the government would always bail out Fannie and Freddie, despite the lack of explicit "full faith and credit" insurance, the mortgage spreads over Treasuries would not have increased in 2007 and 2008 nor have remained high after the Federal government takeover. The fact that spreads were positive suggests that market participants attached some likelihood to the government not bailing out Fannie and Freddie (in addition to some differences in the liquidity

of the two instruments). By directly purchasing GSE-debt and GSE-insured MBS, the Fed increased its own financial exposure to the GSEs, increasing the perception that the guarantee was explicit. However, if this were the channel through which the MBS-purchases and GSE-debt purchases affected mortgage spreads, a significantly more straightforward way to achieve the same goal would be to extend, formally and explicitly, the full faith and credit of the United States to Fannie and Freddie, in a similar fashion as it is already extended to Ginnie Mae.

\section{Regression Results with Primary and Secondary Market Mortgage Spreads}

In this section we report the results from the regression analysis using the primary or secondary mortgage interest rate spread as a dependent variable. As discussed above since these 
spreads are not adjusted for prepayment risk it is necessary use some proxy for prepayment risk in the regression, and we use the implied volatility of Treasury yields obtained from options. A residual analysis similar to that for the OAS for primary and secondary market mortgage spreads shows that the volume of purchases has little or no additional effect beyond the existence of the program. Therefore, we simply use program dummies and estimate the size and quantitative significance of the program.

Table 6 examines the primary mortgage spread using the GSE bond spread series as the proxy for default risk. Observe that higher GSE bond spreads, indicating larger MBS default risk, are associated with higher primary mortgage spreads. The regression coefficient is reasonably close to unity. A higher implied volatility, the prepayment risk proxy, is also associated with higher mortgage interest rates, as predicted by the theory. The coefficients on the various program dummies are small and often statistically insignificant.

Table 6: Primary Mortgage Spread Regressions with GSE bond spreads

\begin{tabular}{|c|c|c|c|c|c|c|}
\hline & (1) & (2) & (3) & (4) & (5) & (6) \\
\hline & OLS & IV & OLS & IV & OLS & IV \\
\hline Bond spreads & $\begin{array}{c}1.09 \\
(0.11)\end{array}$ & $\begin{array}{c}0.86 \\
(0.16)\end{array}$ & $\begin{array}{c}0.99 \\
(0.12)\end{array}$ & $\begin{array}{c}1.02 \\
(0.17)\end{array}$ & $\begin{array}{c}1.21 \\
(0.12)\end{array}$ & $\begin{array}{c}1.16 \\
(0.18)\end{array}$ \\
\hline Implied Volatility & $\begin{array}{c}0.18 \\
(0.09)\end{array}$ & $\begin{array}{c}0.30 \\
(0.11)\end{array}$ & $\begin{array}{c}0.20 \\
(0.08)\end{array}$ & $\begin{array}{c}0.19 \\
(0.10)\end{array}$ & $\begin{array}{c}0.06 \\
(0.09)\end{array}$ & $\begin{array}{c}0.07 \\
(0.11)\end{array}$ \\
\hline $\begin{array}{l}\text { MBS Treasury } \\
\text { Dummy }\end{array}$ & $\begin{array}{l}-7.37 \\
(5.53)\end{array}$ & $\begin{array}{l}-10.96 \\
(6.50)\end{array}$ & & & & \\
\hline MBS Fed Dummy & & & $\begin{array}{l}-13.37 \\
(5.37)\end{array}$ & $\begin{array}{l}-12.60 \\
(6.35)\end{array}$ & & \\
\hline $\begin{array}{l}\text { MBS Fed Announce } \\
\text { Dummy }\end{array}$ & & & & & $\begin{array}{c}4.59 \\
(5.56)\end{array}$ & $\begin{array}{c}5.58 \\
(6.72)\end{array}$ \\
\hline $\begin{array}{l}\text { Number of } \\
\text { Observations }\end{array}$ & 152 & 144 & 152 & 144 & 152 & 144 \\
\hline $\mathrm{R}^{2}$ & 0.667 & 0.638 & 0.677 & 0.657 & 0.665 & 0.647 \\
\hline
\end{tabular}


The regressions in Table 7 show the effects of purchases on primary mortgage rates, but control for the GSE-default risk with the subordinated debt spread rather than the senior GSEdebt spread. Using this risk measure, we obtain estimates of the effects of MBS purchase program which are similar in size to the case of Treasury OAS - a reduction of the primary mortgage rate spread of approximately 30bps due to the MBS purchase program.

Table 7: Primary Mortgage Spread Regressions with Subordinated Debt Spreads

\begin{tabular}{|c|c|c|c|c|c|c|}
\hline & (1) & (2) & (3) & (4) & (5) & (6) \\
\hline & OLS & IV & OLS & IV & OLS & IV \\
\hline Subdebt spread & $\begin{array}{c}0.31 \\
(0.03)\end{array}$ & $\begin{array}{c}0.30 \\
(0.04)\end{array}$ & $\begin{array}{c}0.30 \\
(0.03)\end{array}$ & $\begin{array}{c}0.34 \\
(0.03)\end{array}$ & $\begin{array}{c}0.31 \\
(0.03)\end{array}$ & $\begin{array}{c}0.31 \\
(0.04)\end{array}$ \\
\hline Implied Volatility & $\begin{array}{c}0.42 \\
(0.06)\end{array}$ & $\begin{array}{c}0.46 \\
(0.08)\end{array}$ & $\begin{array}{c}0.31 \\
(0.05)\end{array}$ & $\begin{array}{c}0.26 \\
(0.06)\end{array}$ & $\begin{array}{c}0.32 \\
(0.06)\end{array}$ & $\begin{array}{c}0.32 \\
(0.07)\end{array}$ \\
\hline $\begin{array}{l}\text { MBS Treasury } \\
\text { Dummy }\end{array}$ & $\begin{array}{l}-31.75 \\
(4.63)\end{array}$ & $\begin{array}{l}-33.88 \\
(5.25)\end{array}$ & & & & \\
\hline MBS Fed Dummy & & & $\begin{array}{l}-34.69 \\
(3.94)\end{array}$ & $\begin{array}{l}-37.28 \\
(4.38)\end{array}$ & & \\
\hline $\begin{array}{l}\text { MBS Fed Announce } \\
\text { Dummy }\end{array}$ & & & & & $\begin{array}{l}-25.89 \\
(4.36)\end{array}$ & $\begin{array}{l}-26.94 \\
(4.86)\end{array}$ \\
\hline $\begin{array}{c}\text { Number of } \\
\text { Observations }\end{array}$ & 152 & 144 & 152 & 144 & 152 & 144 \\
\hline $\mathrm{R}^{2}$ & 0.714 & 0.700 & 0.753 & 0.748 & 0.700 & 0.679 \\
\hline
\end{tabular}

Finally, Tables 8 and 9 show the impact of MBS purchases on secondary mortgage spreads. These are the secondary market yields on GSE-insured mortgage-backed securities. 
Table 8: Secondary Mortgage Spread Regression with GSE bond spreads

\begin{tabular}{|c|c|c|c|c|c|c|}
\hline & (1) & (2) & (3) & (4) & (5) & (6) \\
\hline & OLS & IV & OLS & IV & OLS & IV \\
\hline Bond spreads & $\begin{array}{c}0.98 \\
(0.06)\end{array}$ & $\begin{array}{c}0.87 \\
(0.09)\end{array}$ & $\begin{array}{c}0.89 \\
(0.07)\end{array}$ & $\begin{array}{c}0.82 \\
(0.10)\end{array}$ & $\begin{array}{c}0.89 \\
(0.08)\end{array}$ & $\begin{array}{c}0.79 \\
(0.11)\end{array}$ \\
\hline Implied Volatility & $\begin{array}{c}0.20 \\
(0.05)\end{array}$ & $\begin{array}{c}0.27 \\
(0.06)\end{array}$ & $\begin{array}{c}0.07 \\
(0.05)\end{array}$ & $\begin{array}{c}0.10 \\
(0.06)\end{array}$ & $\begin{array}{c}0.12 \\
(0.05)\end{array}$ & $\begin{array}{c}0.17 \\
(0.07)\end{array}$ \\
\hline $\begin{array}{l}\text { MBS Treasury } \\
\text { Dummy }\end{array}$ & $\begin{array}{l}-37.68 \\
(3.07)\end{array}$ & $\begin{array}{l}-40.49 \\
(4.57)\end{array}$ & & & & \\
\hline MBS Fed Dummy & & & $\begin{array}{l}-35.48 \\
(3.15)\end{array}$ & $\begin{array}{l}-37.02 \\
(3.71)\end{array}$ & & \\
\hline $\begin{array}{l}\text { MBS Fed Announce } \\
\text { Dummy }\end{array}$ & & & & & $\begin{array}{l}-33.57 \\
(3.39)\end{array}$ & $\begin{array}{l}-35.68 \\
(4.11)\end{array}$ \\
\hline $\begin{array}{l}\text { Number of } \\
\text { Observations }\end{array}$ & 152 & 144 & 152 & 144 & 152 & 144 \\
\hline $\mathrm{R}^{2}$ & 0.861 & 0.842 & 0.850 & 0.832 & 0.832 & 0.811 \\
\hline
\end{tabular}

The effect of MBS purchase program on the secondary market spread shown in Table 8 are slightly higher than the effect on primary market spreads shown in Table 6. Of all the results reported in this paper the largest effects are Table 9 where we used the subordinated debt as the proxy for risk. Comparing Tables 8 and 9 with Tables 6 and 7 suggests that this reduction in secondary market funding costs for mortgage lenders was only partially passed on to consumers in terms of lower primary mortgage rates. Observe that using the IV approach gives effects of the MBS-purchases of a larger magnitude than the OLS approach 
Table 9: Secondary Mortgage Spread Regression with Subordinated Debt Spreads

\begin{tabular}{|c|c|c|c|c|c|c|}
\hline & (1) & $(2)$ & (3) & (4) & (5) & (6) \\
\hline & OLS & IV & OLS & IV & OLS & IV \\
\hline Subdebt spread & $\begin{array}{c}0.22 \\
(0.02)\end{array}$ & $\begin{array}{c}0.22 \\
(0.03)\end{array}$ & $\begin{array}{c}0.19 \\
(0.02)\end{array}$ & $\begin{array}{c}0.21 \\
(0.03)\end{array}$ & $\begin{array}{c}0.21 \\
(0.02)\end{array}$ & $\begin{array}{c}0.22 \\
(0.03)\end{array}$ \\
\hline Implied Volatility & $\begin{array}{c}0.50 \\
(0.05)\end{array}$ & $\begin{array}{c}0.53 \\
(0.05)\end{array}$ & $\begin{array}{c}0.26 \\
(0.04)\end{array}$ & $\begin{array}{c}0.24 \\
(0.05)\end{array}$ & $\begin{array}{c}0.33 \\
(0.04)\end{array}$ & $\begin{array}{c}0.33 \\
(0.05)\end{array}$ \\
\hline $\begin{array}{l}\text { MBS Treasury } \\
\text { Dummy }\end{array}$ & $\begin{array}{l}-59.51 \\
(3.29)\end{array}$ & $\begin{array}{l}-61.94 \\
(3.73)\end{array}$ & & & & \\
\hline MBS Fed Dummy & & & $\begin{array}{l}-55.25 \\
(2.91)\end{array}$ & $\begin{array}{l}-56.81 \\
(3.22)\end{array}$ & & \\
\hline $\begin{array}{l}\text { MBS Fed Announce } \\
\text { Dummy }\end{array}$ & & & & & $\begin{array}{l}-56.05 \\
(2.79)\end{array}$ & $\begin{array}{l}-57.87 \\
(3.10)\end{array}$ \\
\hline $\begin{array}{l}\text { Number of } \\
\text { Observations }\end{array}$ & 152 & 144 & 152 & 144 & 152 & 144 \\
\hline $\mathrm{R}^{2}$ & 0.805 & 0.783 & 0.817 & 0.796 & 0.831 & 0.813 \\
\hline
\end{tabular}

\section{Conclusion}

In this paper we endeavored to estimate the quantitative impact of the Federal Reserve’s Mortgage Backed Securities Purchase program on mortgage interest rates using a multivariate statistical framework which takes account of other possible influences on rates. We focused on two other possible influences: changes in prepayment risk and changes in default risk. Our results can be summarized as follows:

o Using conventional optional adjusted spreads (OAS) based on LIBOR swaps to control for prepayment risks, we find that the MBS program has no significant effect. Movements in prepayment risk and default risk explain virtually all of the movements in mortgage spreads. In particular, the declines in the OAS that have 
occurred during the period of the MBS program can be better explained by a general decline in risk.

o A more significant effect on mortgage spreads—about 30 basis points—can be found if one uses an alternative measure of OAS based on the Treasury yield curve, but even with this measure the volume of purchases has no effect over and above the mere existence of the program. In other words the impact has not increased with the additional purchases of MBS since the start of the program. The higher estimated impact of Treasury-OAS compared with Swap-OAS is related to movements in the so called TED spread between LIBOR and Treasury rates which is unrelated to the MBS program.

o Estimating the impact using indirect methods to control for prepayment risk generally confirms the analysis using OAS, but shows larger effects in the secondary market. The impact of the program on primary market spreads ranges from the wrong sign and insignificant to around 30 basis points. For secondary market rates the impact is larger-in the 30 to 60 basis point range-which corresponds to a less than full pass through of the impact to primary mortgage spreads. In general we find somewhat smaller effects when we control for default risk using senior agency debt than we do with subordinated agency debt or instrumental variables.

We emphasize that analyzing the effectiveness of the MBS purchase program is very difficult. The creation of adequate counterfactuals is complicated by the simultaneous government interventions in a large number of markets. Furthermore, the conservatorship-status 
of the GSEs has contaminated many of the relevant GSE-default risk proxies that are most important to control for when analyzing the development of spreads on GSE-insured MBS. Our analysis has used a variety of different approaches to proxy for risk, each with its own problems. However, none of the approaches reported in this paper, nor others we examined — such as CDS-series for the largest mortgage lenders such as Bank of America, Wells Fargo, Citi and JP Morgan - provides evidence that the volume of MBS purchases is contributing in a major way to the decline in mortgage interest rates.

Currently there is a lack of publicly-available statistical studies on the effectiveness of the Fed's program. We note that our estimates of the impact are much smaller than the impacts reported in the recent speech by Sack (2009). While this paper is certainly not the final word on the program's effectiveness, our empirical results raise questions about the ability of central banks to conduct price-keeping operations reliably by increasing and decreasing asset purchases in particular markets. They also raise doubts about the benefits in terms of lower mortgage interest rates of further increases in the size of the Fed's MBS portfolio or about the costs in terms of higher interest rates of gradually reducing the size of that portfolio. 


\section{$\underline{\text { References }}$}

Bernanke, Ben S. (2009), “The Crisis and the Policy Response,” Stamp Lecture, London School of Economics, London, England, January 13, 2009

Federal Open Market Committee, Minutes, June 23-24, 2009

Cerrato, M. and Djennad, A. (2008) “Dynamic Option Adjusted Spread and the Value of Mortgage Backed Securities”, http://www.gla.ac.uk/media/media_117452_en.pdf

Ciorciari, John D. and Taylor, John B, eds. (2009), The Road Ahead for the Fed, by George Shultz, Allan Meltzer, Peter Fisher, Donald Kohn, James Hamilton, John Taylor, Myron Scholes, Darrell Duffie, Andrew Crockett, Michael Halloran, Richard Herring, and John Ciorciari

Fabozzi, Frank and Steven Mann (2001), “Introduction to fixed income analytics”, New Hope Publisher

Kupiec, Paul and Adama Kah (1999), “On the Origin and Interpretation of OAS”, The Journal of Fixed Income, vol. 9(3)

Lehnert, Andreas, S. Wayne Passmore and Shane M. Sherlund (2006) “GSEs, Mortgage Rates, and Secondary Market Activities,” Federal Reserve Board of Governors, September, FEDS Working Paper 2006-30

Sack, Brian, “The Fed's Expanded Balance Sheet”, Remarks at the Money Marketeers of NYU, http://www.newyorkfed.org/newsevents/speeches/2009/sac091202.html, December 2, 2009

Smith, Josephine M. (2009), “The Term structure of Money Market Spreads during the Financial Crisis.” Working Paper, Stanford University 
Spahr, Ronald and Mark Sunderman (1994), “The Effect of Prepayment Modeling in Pricing Mortgage-Backed Securities,” Journal of Housing Research vol. 3(2)

Taylor, John B. (2009), “Empirically Evaluating Economic Policy in Real Time”, Martin Feldstein Lecture, National Bureau of Economic Research, July 10. Video: http://www.nber.org/feldstein_lecture/feldsteinlecture_2009.html, NBER Reporter, No. 3, 2009.

Taylor, John B., John C. Williams (2009), “A Black Swan in the Money Market”, American Economic Journal: Macroeconomics, American Economic Association, vol. 1(1), pages 58-83, January.

Windas, Thomas (1996), “An introduction to option-adjusted spread analysis”, Revised Edition, Bloomberg Press 


\section{$\underline{\text { Appendix - A primer on OAS valuation }^{11}}$}

MBS are an example of a non-bullet fixed income security that has a payment stream which is dependent on the level of the prevailing interest rate. Provisions allowing for borrower prepayment prior to the maturity of a loan are referred to as embedded options. In the case of MBS, when interest rates decline, mortgage holders might choose to prepay their mortgage and refinance at lower rates. This terminates the investors' source of above-market returns, and requires them to reinvest at lower prevailing rates. To compensate the investor for the presence of this prepayment option, coupon payments on MBS must be adjusted upwards.

The pricing of mortgages and mortgage-backed securities is typically done using Monte Carlo methods. Multiple possible interest rate scenarios are generated using a stochastic interest rate process. Under the equivalent martingale approach, a stochastic path of interest rates is calibrated that eliminates arbitrage opportunities with respect to the observed term structure (in the econometric analysis above, we consider both Treasury CMT and LIBOR Swap curves). Along each interest rate path, a prepayment model generates cash flows as a function of the simulated interest levels ${ }^{12}$. For an overview of possible prepayment models, see Spahr and Sunderman (1994). Therefore, OAS calculations are necessarily dependent on the interest rate model and the prepayment model used. The projected cash flows from the MBS in every state are then discounted backwards using the appropriate interest rate. The OAS is the spread over the chosen yield curve that equates the PV generated using the adjusted yield curve to the market price of the security.

\footnotetext{
11 This Appendix is based heavily on Kupiec and Kah (1999) and Windas (1996)

${ }^{12}$ In reality, the exercise of the prepayment option is also dependent on factors other than the interest rate, such as seasonality and trends in home prices, etc.
} 
To show this formally, let $\left\{r_{i t}\right\}$ represent the development of interest rates in time $t$ on path $i$. Let $\left\{C_{i t}\right\}$ represent the anticipated cash-flows in each period $t$ on path $i$. $C_{i t}$ is determined using the prepayment model. The present value of the cash-flows for each path $i$ is given by:

$$
P V_{i}=\sum_{k=1}^{K} \frac{C_{i k}}{\Pi_{j=1}^{k}\left(1+r_{i j}\right)}
$$

The associated value, $P_{E}$, of the MBS should thus be the (weighted) average of the PVs.

$$
P_{E}=\frac{1}{N} \sum_{i=1}^{N} w(i) P V_{i} \text { s.t. } \sum_{i=1}^{N} w(i)=1
$$

The option-adjusted spread (OAS) is then derived by comparing the market price of an MBS, $\mathrm{P}_{\mathrm{M}}$, to $\mathrm{P}_{\mathrm{E}}$. In particular, it is calculated as the spread over the term structure that equates the market price to the (weighted) average present value of expected cash flows over all simulated paths. More formally, the OAS is defined as the $\theta$ such that:

$$
P_{M}=\frac{1}{N} \sum_{i=1}^{N} w(i)\left[\sum_{k=1}^{K} \frac{C_{i k}}{\Pi_{j=1}^{k}\left(1+r_{i j}+\theta\right)}\right]
$$

